Article

\title{
"They Sold Us Illusions": Informality, Redevelopment, and the Politics of Limpieza in the Dominican Republic
}

\author{
Raksha Vasudevan and Bjørn Sletto * \\ Program in Community and Regional Planning, University of Texas at Austin, Austin, TX 78712, USA; \\ E-Mails: rakshav@utexas.edu (R.V.), bjorn@utexas.edu (B.S.) \\ * Corresponding author
}

Submitted: 13 April 2020 | Accepted: 15 June 2020 | Published: 31 August 2020

\begin{abstract}
In the capital city of Santo Domingo, Dominican Republic, climate change and environmental concerns are used to justify massive redevelopment projects in informal settlements located along the rivers Ozama and Isabela. Residents in such river communities negotiate the uncertainty of state planning under a new socio-environmentalism that prioritizes the environment over social concerns, while continuing to pursue bottom-up neighborhood planning despite the powerful rationality of limpieza (cleanliness), the pervasive techniques of responsibilization, and the celebratory spectacles of megaprojects. The uncertainty resulting from governance under socio-environmentalism produces ambivalence towards environmentcentered projects among residents. Drawing on oral histories and interviews with long-time community members, we suggest that residents engage in three 'sensemaking strategies' to process their ambivalence in the face of daily precarity, in particular the ongoing threat of evictions. Residents 'keep up' with the state and strategically utilize planning language to advocate for community priorities. They engage in practices of storytelling that reproduce a deep sense of community and provide a longer historical understanding of planning interventions. Finally, through verbal speculation and other 'unsanctioned speech acts' they analyze disruptions caused by socio-environmentalism, build solidarity with other communities, and think ahead despite uncertainty.
\end{abstract}

\section{Keywords}

climate change; community-based planning; community organizing; Dominican Republic; informality; Latin America; oral history; redevelopment; speculation; storytelling

Issue

This article is part of the issue "Cities of Inclusion-Spaces of Justice" edited by Anja Nygren (University of Helsinki, Finland) and Florencia Quesada (University of Helsinki, Finland).

(C) 2020 by the authors; licensee Cogitatio (Lisbon, Portugal). This article is licensed under a Creative Commons Attribution 4.0 International License (CC BY).

\section{Introduction}

During the current presidency of Danilo Medina, the central government of the Dominican Republic has prioritized cleanup and beautification efforts of the OzamaIsabela river basin in the Province of Santo Domingo. Pointing to flooding, contamination, and health concerns impacting informal river communities located within the basin, the government has capitalized on a variety of international public-private partnerships to not only fund efforts around environmental cleanup, but also to develop an 'integrated strategy' that includes climate adap- tation, economic development, and improved housing and community amenities.

However, these planning efforts obscure the ways in which the central government, as the capital city's major planning actor, and related institutions are failing to meet the basic needs of residents of river communities. Specifically, in the case of Santo Domingo we argue that a discourse of socio-environmentalism has reconfigured responsibilization tactics characteristic of neoliberal governance. This discourse of socio-environmentalism has local and global sympathizers as it responds to current climate change concerns, enabling the central gov- 
ernment to frame the rationality of limpieza (cleanliness) as a reflection of the state's commitment to social good. By deploying neoliberal techniques of responsibilization (Gunder \& Hillier, 2007; Sletto \& Nygren, 2016; Swyngedouw, 2005) through the logic of citizen participation in environmental risk and waste management, authorities are able to forestall opposition to planning projects that are interventionist and often violent. Moreover, Santo Domingo presents a fragmented (Balbo, 1993; Koch, 2015; Larbi, 1996) planning landscape with unclear division of responsibility and poor communication between planning agencies and communities, leaving residents in a state of suspension (Roy, 2005) with great uncertainty about the intent and timing of future planning actions.

This article examines how river communities negotiate the uncertainty of state planning under socioenvironmentalism, understood as a form of governmentality that seeks to develop compliant subjectivities through governance techniques premised on citizen participation and individual responsibility (Raco, 2007; Rydin, 2007). The production of these socioenvironmental subjectivities is shaped by a powerful discourse of climate change and driven by a paradigm of sustainable development, which in turn serve to frame infrastructure and redevelopment projects in river communities as common-sensical interventions deserving of local support. Meanwhile, a rationality of participation that has long defined Dominican environmental governance (Sletto \& Nygren, 2016) serves to bolster the disciplining of residents in river communities, prompting them to assume responsibility for their own environmental welfare while depoliticizing the violence of limpieza, evictions, and erasure of homes. This production of the socio-environmental subject through techniques of responsibilization thus permits the privileging of environmental cleanup and climate adaptation measures over human quality of life concerns.

In the following, we focus in particular on the ways in which residents continue to critically assess state planning strategies and pursue bottom-up neighborhood planning (Thomas, 2004) despite the powerful rationality of limpieza, the pervasive techniques of responsibilization, and the celebratory spectacles of megaprojects. In so doing, we situate this article within planning scholarship that sees and theorizes from 'global south' contexts (Kudva, 2009; Miraftab, 2009; Roy, 2009), foregrounding the practices and meaning-making of residents that are typically overlooked in planning research and processes. Drawing on oral histories and interviews with long-time community members, we suggest that residents engage in three 'sensemaking strategies' to process their ambivalence in the face of daily precarity, in particular the ongoing threat of evictions, and thus make sense of a fragmented and unpredictable planning regime. First, we suggest the sensemaking strategy of 'keeping up' with the state involves developing literacy around plans and planning language, the better to utilize these represen- tational strategies as needed in their own claims-making. A second strategy involves holding close and repeating personal stories of the land and the community that encompass a longer arc than an election cycle, thus reproducing a sense of community. Finally, deeper analysis of oral histories reveals verbal speculation about the future through "unsanctioned speech acts" (Derby, 2014, p. 131), which enable residents to cope with the lack of clarity around planning processes.

All three sensemaking strategies inform a tradition of bottom-up neighborhood planning that is grounded in the logics of community building and caretaking, while at the same time allowing residents to hold and process both optimism and skepticism towards state planning efforts. While residents point to the historical failure of city and national governments to meet even the most basic needs of their communities, they also voice support of planning interventions that comport with their own traditions of placemaking and caretaking. Attention to sensemaking strategies, therefore, reveals the ways in which people attribute meaning to complex, paradoxical, and contradictory experiences, and, in turn, how meanings inform identity and action (Weick, Sutcliffe, \& Obstfeld, 2005), thus furthering a deeper understanding of how residents negotiate and engage with complicated and obscure planning processes over time.

We reflect specifically on residents' experiences and sensemaking strategies in the neighborhoods of Los Guandules, La Ciénaga, and La Zurza. Since 2014, La Ciénaga and Los Guandules have been the site of a contentious partial redevelopment called Nuevo Domingo Savio involving the displacement of a number of residents, while La Zurza has seen the development of a new riverfront street as part of the central government's redevelopment efforts. Residents in all three neighborhoods have experience with bottom-up planning efforts but also share vivid memories of past interventions, including a complete redevelopment and relocation plan, Nueva Barquita, that President Medina completed early in his Presidency to resettle residents in the river community of La Barquita just to the east of La Zurza. In this article, we draw on conversations surrounding the ongoing Nuevo Domingo Savio redevelopment project to demonstrate the complex, varied, and situated ways in which residents manage threat of evictions through strategies of sensemaking. In doing so, we situate the Nuevo Domingo Savio project and the resulting evictions within a larger history of precarity that river communities have had to manage.

\section{Context}

\subsection{Research Site}

La Ciénaga and Los Guandules are two of the oldest river communities in the capital city, first settled in the late 1950s, while La Zurza was established in the 1960 s by migrants from other parts of the Dominican Republic 
and Haiti. These river communities and others like them are primarily located in Circunscripción 3, one of the three census districts that constitute the capital area of Santo Domingo, Distrito Nacional (National District). Circunscripción 3 primarily contains urbanized land, has the greatest population density in the city, and the greatest percentage of households living in multidimensional poverty (Alcaldía Distrito Nacional, 2019, pp. 34-35). The neighborhoods also have the lowest quality construction materials, and many neighborhoods lack access to basic services such as drinking water, electricity, and sanitation services (Alcaldía Distrito Nacional, 2019). River communities in Circunscripción 3 have seen varying levels of consolidation over time, primarily through the multigenerational work of residents and community organizations. Over the years, and depending on the central government's redevelopment strategies at the time, parts of these communities have been subjected to threats of evictions or displacement.

According to the Global Climate Risk Index of 2015, the Dominican Republic is the eighth-most affected country by climate change (International City/County Management Association, 2018, p. 10). Drought, temperature increase, sea level rise, increased salinity in water tables, tropical cyclones, and lack of potable water are among the environmental risks facing the country and the Santo Domingo metropolitan area (Alcaldía Distrito Nacional, 2019). In the National District, those living by the sea face the greatest risk, as well as those living by the Ozama and Isabela Rivers because of river and stream floods. The area of vulnerable land in river communities totals $17.56 \mathrm{~km}^{2}(19.17 \%$ of the city), placing roughly 292,332 residents (30.29\% of the city's total) at risk (Alcaldía Distrito Nacional, 2019, p. 35). The numerous cañadas (creeks) that traverse the city have created micro-watersheds that make the land even more vulnerable during flooding and extreme rainfall, causing landslides and exacerbating public health concerns. In an initial diagnostic study conducted by Fundación Tropigás Natural, river communities are characteristically portrayed as a primary cause of the environmental degradation of the riverbanks: "Disorganized urban settlements and industrial development on the (river) banks are the main causes of this serious situation. The multiple discharge sources produce a decomposition that affects color, generates bad odors, and alters the nature of the waters" (Gutiérrez, 2014, p. 4).

Beginning in the 1990s, neoliberal governance led to decentralization strategies and an emphasis on economic development which in turn prompted the local and central governments to reduce their investment in social infrastructure in Circunscripción 3 (Bosman \& Amen, 2006; Goldfrank \& Schrank, 2009). At the same time, however, because of the powerful logic of limpieza and the lack of accountability by public institutions due to the fractured planning regime in the Dominican Republic, major environmental cleanup projects on the Ozama and Isabela River associated with the discourse of socio-environmentalism have been implemented with little to no resistance. In particular, the past presidency of Leonel Fernández (2004-2012) and the current administration of Danilo Medina (2012-present) have favored spectacle infrastructure projects, including the construction of the Santo Domingo Metro, the Santo Domingo Teleférico (cable car), and the massive housing project Nueva Barquita, which serve to obscure community impacts of limpieza projects.

Since Santo Domingo is the capital city, two central government plans are particularly important in reproducing this new form of socio-environmentalism in Circunscripción 3. The first, the National Development Strategy 2030 (Estrategia Nacional de Desarrollo 2030), was conceived as a 'unifying' national document intended to guide government and private investment in the country's institutional, social, economic, and environmental sectors until 2030, regardless of which party is in power (Ministerio De Economía, Planificación $Y$ Desarrollo, n.d., p. 14). In its vision of the future Dominican Republic, the National Development Strategy 2030 foregrounds individual responsibility as an essential element of citizenship: "A prosperous country where one lives with dignity, security and peace, with equal opportunities in a framework of participatory democracy, responsible citizenship, and competitive insertion into the global economy that takes advantage of resources to develop innovatively and sustainably" (Ministerio De Economía, Planificación Y Desarrollo, n.d., p. 25).

The second, the Ozama-Isabela Strategic Plan 2015-2030 (Plan Estratégico Ozama-Isabela 2015-2030), is specifically focused on the Ozama-Isabela river basin. The plan offers an integrated development strategy centred on the social and environmental challenges of the Ozama-Isabela river basin, pointing to excessive population growth, environmental pollution, and deterioration of the rivers as principal areas of concern. Calling for sustainable development as a framework for growth and investment in the river basin, the OzamaIsabela Strategic Plan 2015-2030 is framed as a plan for economic development tampered by a modicum of necessary environmental and social changes (Comisión Presidencial, 2015).

The ongoing redevelopment project most visible under the Ozama-Isabela Strategic Plan is Nuevo Domingo Savio in La Ciénaga and Los Guandules. In conjunction with the Ozama-Isabela Strategic Plan, in 2013 President Medina created URBE: Unidad Ejecutora Para La Readecuación de La Barquita y Entornos (Executive Unit for the Redevelopment of La Barquita and Surroundings) through an emergency decree after his visit to La Barquita, another community located on the banks of the River Ozama. Initially, the office was responsible for developing an intervention protocol in vulnerable communities around the Ozama-River basin. Now, its purview has expanded to oversee all spectacle projects of the current President. To date, these projects include the Nueva Barquita project that displaced residents of 
La Barquita to a newly constructed development, the Ecological Park being constructed where the La Barquita neighborhood used to be, the Teleférico (cable car line) that connects the two metro lines in Santo Domingo, and the Nuevo Domingo Savio project.

Initiated in 2014 and directed by URBE, Nuevo Domingo Savio is slated to be completed this year in conjunction with the end of the presidential term (J. Millet, personal communication, June 7, 2019). When asked how the area was chosen for redevelopment, Millet points to the dangers of flooding, stating that nearly $60 \%$ of Domingo Savio (encompassing the river communities of La Ciénaga and Los Guandules) is at risk of flooding and highly vulnerable to hurricanes. Deploying the logic of limpieza and its appeal to socio-environmental rationality, he suggests that overpopulation over time and the lack of "formal planning" led to people "occupying the territory, throwing trash in the river." Because of the failure of responsibility on the part of residents, Millet argues, a park will be developed:

Along the edge of the river so that they (the residents who are evicted) do not return to occupy this area....If (the area) is left without being used, people could move back in (over the course of just) one night.

However, while the discourse of socio-environmentalism drives plan-making and shapes the development of environmentally responsible subjects in the Ozama-Isabela river basin, river communities share a long history of organizing and incrementally improving their own neighborhoods despite variable investment from the government. In La Ciénaga and Los Guandules, residents recall the community-based development of Plan Cigua. Published in 2004, the Plan de Desarrollo para La Ciénaga y Los Guandules (Development Plan for La Ciénaga and Los Guandules) includes an assessment of conditions in La Ciénaga and Los Guandules, a rezoning strategy, and a process to relocate some of the residents. The plan-making process was referred to as "a protest movement with proposals" ("un movimiento de protesta con propuestas"; Codecigua with Ciudad Alternativa, 2004, p. 7). Thus the work of residents have long been fundamental to incremental improvements in river communities, fueling their retrospections of community-based action and providing resources for sensemaking in the face of recent state interventions.

\subsection{Methods}

This article draws on a combined 17 years of field research in Santo Domingo. The oral histories described in this article emerged from Vasudevan's broader feminist ethnography project to understand the socio-spatial mobilities and everyday experiences of residents in La Zurza. The project included ethnographic fieldwork and participant observation, semi-structured interviews, plan analysis, and oral histories. Interviews were conducted with thirty-five planning stakeholders, including local and central government planners and policymakers, representatives from national and international development organizations, community-based planning actors, and independent architects and planners in the city of Santo Domingo.

Sletto has more than 12 years of experience working with river communities and maintaining governmental and academic partnerships in the Dominican Republic. For 10 years, he also conducted a long-term studio project with another river community, Los Platanitos, in Santo Domingo Norte. Long-term relationship-building with institutional and community partners enabled us to develop a grounded analysis of planning and urban development in Santo Domingo and its impact on river communities.

To provide insight into the ways in which sensemaking strategies inform bottom-up planning in river communities in Santo Domingo, we draw from community plans but center residents' oral histories. Oral histories were conducted with ten long-time residents in La Zurza, La Ciénaga, and Los Guandules, several of whom were among the first to settle in and organize their neighborhoods. As Thomas (2004) notes, oral history provides a unique perspective on bottom-up neighborhood planning, i.e., a form of planning that "aims to plan for the future in a way that helps create the process of capacitybuilding community development in affected neighborhoods" (p. 52), precisely because it enables residents to reflect on both organizational development and community change. Oral history also "unearths experiences of dedication and sacrifice over time that point towards potential future improvements" (p. 66), and creates a collaborative and empowering process through dialogue as people reflect on the past and look to the future.

A longtime resident and community organizer who was well-known by residents often accompanied Vasudevan during oral history interviews. Since residents felt quite comfortable in his presence, the interviews revealed important information at the margins of the formal oral history narrative through what Derby (2014) calls 'unsanctioned speech acts' or peripheral communication. For Derby, banter, rumor, and gossip are popular forms of knowledge production in the Caribbean that are typically excluded from historical analyses. We found that the rumors and other unsanctioned speech acts that emerged in our interviews provided additional insights into how residents are interpreting ongoing redevelopment processes.

\section{Theory}

\subsection{Fragmentation of the State and Neoliberal Environmental Governance}

The fragmentation (Koch, 2015; Larbi, 1996) or splintering (Roy, 2009; Swilling, 2014) of urban space in the Dominican Republic can be attributed to divisions cre- 
ated during the colonial period. As Balbo (1993) suggests, the continuing fragmentation today stems from rapid population growth in urban areas, the dependency of the urban economy on the informal sector, and the inadequacy of urban planning tools. Relatedly, Swilling (2014) defines 'splintered urbanism' as "an expression in space of the neoliberal project that was first introduced into some leading OECD countries from the late 1970s onwards" where "'commodification' replaced 'universal access' as the primary urbanizing principle of urban governance" (p. 3182).

As a result of this splintering of urban space under neoliberal governance, planning processes typically led by state agencies now involve a host of other actors. In the case of Santo Domingo, various infrastructure agencies such as water utilities and public works, universities, private developers, national and international development agencies, and community-based organizations have emerged as major planning actors (Chantada, 2014; Sletto, 2013). Dominican organizations such as Fundsazurza, COPADEBA, Ciudad Alternativa, and others have assumed responsibility for a range of service provisions in river communities, including trash pickup and transportation infrastructure improvements. Whereas several of these civil society organizations were earlier involved in social movement activities, the fragmentation of governance structures has led these organizations to focus less on radical, broader "social criticism" (Chantada, 2014, p. 587) and demands-making than before. Instead, they have become more reliant on external funding and capacity building to facilitate 'progress' in their communities (J. Candelario, personal communication, June 15, 2018).

Regardless of whether they are based in a local or central government, or university setting, planning actors in Santo Domingo often know each other and move between the public, non-profit and private spheres. This porous boundary between public and private spheres also impacts the plan-making process, as limited central and local government resources require state planners to rely on agents from other sectors to contribute with funding, technical capacity, and political influence (Sletto, Tabory, \& Strickler, 2019). To complicate the planning landscape even further, Santo Domingo falls under the purview of both city and state agencies, leading to lack of coordination and competing purposes between state agents. For river communities, this has meant navigating shifting and confusing relationships, not only with planning agencies but also with a host of other planning actors.

\subsection{Responsibilization of Citizens}

In Latin America, techniques of responsibilization under neoliberal governance place the onus on civil society actors to take charge of their own well-being. 'Active citizenship' by marginalized groups used to be defined by social movements through conceptualizations of rights to the city and rights to difference (Dagnino, 2006). However, under neoliberalism, new governance arrangements have altered relationships between the state and civil society while also changing what political citizenship entails (Swyngedouw, 2005). In a neoliberal context where market-based mechanisms shape the planning landscape, authority structures that foreground governance through responsibilization place the onus on market-rational individuals to be autonomous, prudent, and entrepreneurial citizens (Woolford \& Nelund, 2013) who assume responsibility for their own welfare (Raco, 2007; Rydin, 2007; Shamir, 2008).

In the case of Santo Domingo, we argue that techniques of responsibilization serve to depoliticize opaque and disruptive state interventions in river communities. For example, Santo Domingo Soy Yo (I Am Santo Domingo) is a citizen education campaign initiated by the municipal government that focuses on environmental and cultural education, calling on community groups and individuals to perform trash collection, cleanup efforts, and other preservation activities around the city: "(The campaign) aims to incorporate environmental education in municipal policy initiatives with the purpose of sponsoring the participation of people in the construction of a responsible citizenry committed to city pride" (Alcaldía Distrito Nacional, n.d.). Similarly, as highlighted in the Ozama-Isabela Strategic Plan, Verde Somos Todos (We Are All Green) is another, proposed environmental education program by the central government aimed at "creating a green and sustainable culture and mentality among populations in the river basin" (Comisión Presidencial, 2015, p. 34)."

Thus the narrative of limpieza coupled with the imperatives of economic development lead to the commonsensical prioritization of near-term, urgent care for the environment despite the threat of displacement, while residents in river communities continue to be responsible for their own well-being. As Sletto and Nygren (2016, p. 5) state, "through 'structures of inclusion' characteristic of neoliberal governance, participation becomes delinked from any projects of emancipation and instead conceived of as a 'loose toolkit' for 'good governance."' The reconfiguration of responsibilization through the discourse of socio-environmentalism has worked particularly well in river communities, precisely because state planners' professed goals to maintain clean rivers and a healthy environment is shared by residents and community-based planning actors.

\subsection{Making Sense of Change}

Even while techniques of responsibilization serve to depoliticize redevelopment projects in river communities, residents actively work to make sense of a complex planning regime and its impact in their communities. The concept of sensemaking allows us to link the meanings that residents take from planning experiences over time to their identity-formations and actions as residents. 
Sensemaking refers to the "interplay between action and interpretation," beginning with ordering events and then 'bracketing' and 'labeling' events into meaningful classifications, accommodating larger social or systemic factors with an intention of future action (Weick et al., 2005, p. 410). By highlighting the dialectical relationship between talk and action (Hutter \& Kuhlicke, 2013), this conceptualization of meaning-making reveals how actors construct understanding and articulate potential action through retrospective reflection on past planning events.

As Weick et al. (2005) suggest, "explicit efforts at sensemaking tend to occur when the current state of the world is perceived to be different from the expected state of the world, or when there is no obvious way to engage the world" (p. 409). In river communities, where residents feel ambivalent towards current redevelopment projects, we find that oral histories reveal more explicit forms of making sense of the effects of planning and redevelopment, while unsanctioned speech acts emerge as a tacit form of sensemaking. As Derby (2014) notes, 'vernacular speech genres,' or those speech acts such as rumor, gossip, and banter that may not enter formalized spaces of dialogue such as governmental spaces or structured interview spaces, reveal specific ideas, conceptualizations, and metaphors that people deploy to manage, resist, or reframe events that are influencing their lives. All three sensemaking strategies described below enable residents to reflect on the history of government interventions while managing precarity and change.

\section{Findings}

First, despite the fragmented and opaque planning landscape, residents and organizers stay informed and continue to develop literacy around planning-related tools (laws, decrees, plans) that enable them to be strategic in their efforts to intervene in planning processes. Second, they hold onto and tell their personal stories as a means to retain their connection to other residents and to the land. Third, they deploy rumors and other unsanctioned speech acts to speculate on the impacts of urban redevelopment. In this section we reflect on the stories of Doña Martina, Evelin, Dannel, and Alfonzo. We use pseudonyms to protect residents' privacy in light of the ongoing displacement process; because Doña Martina is an elderly woman, it is a sign of respect in Dominican culture to precede her name with 'Doña' (Mrs.). As longtime residents and community organizers, their stories provide meaningful insights into the history of bottomup planning efforts and the responses to state planning interventions over time.

\subsection{Adopting the Language of the State}

10 years prior to the inception of Nuevo Domingo Savio, residents in La Ciénaga and Los Guandules had already developed Plan Cigua, their own communitybased plan based on a participatory process involving community-based organizations, neighborhood groups, and academics. Evelin, a resident of Los Guandules, recalls the Plan Cigua process quite well. She describes how 21 juntas de vecinos (neighborhood organizations) from Los Guandules and fifteen from La Ciénaga, as well as most of the churches in the neighborhood, participated in the development of the Plan. Residents along with technicians from civil society organizations such as Ciudad Alternativa and COPADEBA shared ideas and articulated priorities that were later developed into planning directives. A technical team from Ciudad Alternativa conducted a community census jointly with residents, and finally, proposals were developed in community workshops directed by Ciudad Alternativa.

In her recollections, Evelin demonstrates how community leaders appropriate language used by planners to make sense of and contest a fractured and unpredictable planning regime. According to Evelin, Plan Cigua specified where to construct new homes and facilities and where not to, which was a critical point of conflict within and outside the community. As she recalls, in the years following the development of Plan Cigua, a school was to be constructed in the sub-sector of Los Cocos in Guandules. When approached by a reporter from a newspaper about the project, she let them know that personally she was against the idea of building in that area. Drawing on the language deployed in Plan Cigua, she argued that the sub-sector had been categorized as the site of the biggest cañada in the neighborhood, meaning that it was contaminated by defecation and under constant threat of flooding. Since children would be playing in the vicinity, Evelin was adamantly against the idea of building a school there. She says:

We want to leave the precarity, and for this reason, I was not in agreement with the school there. And immediately, they stopped the construction. You can imagine how I felt - I felt bad...the people who wanted the school were all over me. But thank God I was protected by the Plan Cigua book. Immediately we went to the Public Works Department and inquired, and we could see that there was no soil study, there was no permission to build there. We went to the mayor's office and the same thing happened.... took an engineer and an architect from Ciudad Alternativa because technically I am not anybody, just a community member, and then they could verify what I was saying. And then I felt a bit calmer because this is really not an area where it can be built.

As this excerpt from Evelin's oral history suggests, she became well-versed in the proposals written in Plan Cigua, making it possible for her to deploy planning language and rationalities to press her claims. However, at the same time, her statement reflects her feeling that she does not have the power to make change on her own. Instead, she felt 'protected' by Plan Cigua, using the opportunity provided by the planning process to partner 
with an engineer, the face of Dominican planning rationality, to contest the building of the school.

Dannel, born and raised in the La Clarín sub-sector of La Ciénaga, relates a similar strategy of appropriating technical language to make sense of and contest city planning projects. His parents were some of the first to move to the neighborhood, and Dannel was born and brought up there. He is currently the lead coordinator of El Concejo de Organizaciones de $\mathrm{Fe} y$ Base Comunitarias de La Ciénaga (The Council of Faith and Community-Based Organizations of La Ciénaga), a group that brings together the Evangelical, Catholic, and Adventist churches as well as the junta de vecinos and other community organizations that do social work in the neighborhood.

Dannel, who is younger than Evelin, was not involved with Plan Cigua, but he recalls when President Medina visited the neighborhood in 2015 . His community group had been trying to draw attention to the contamination of the Cañada del Arrosal for a long time, and they decided to take advantage of the President's visit to make the issue more visible. Rather than foment a protest, they presented the President with a petition signed by members of the community. The President read it and actually "came down to La Ciénaga, and walked with us in the interior of the neighborhood.... He spent the night here walking with us through the alleys, and that's when the work began." Community organizations then took advantage of the presidential inauguration in March 2016 to publicly ask the President for help addressing the poor housing conditions in the neighborhood. Since then, his group has maintained a dialogue premised on technical discourse with URBE to influence the development of Nuevo Domingo Savio, which, Dannel says, continues to foreground limpieza and environmental concerns at the expense of social goals.

\subsection{Storytelling}

Unlike Evelin and Dannel, Doña Martina faces the imminent threat of eviction, as the houses in her block are marked with red ' $\mathrm{Xs}$ ' to indicate the area is slated for redevelopment under Nuevo Domingo Savio. Doña Martina's sensemaking is based on organizing actions and episodic events into "an understandable composite" (Polkinghorne, 1988, p. 13), allowing her to position her personal life and community activism within the context of government interventions that she has witnessed over many years. As Little and Froggett (2009, p. 459) argue, as opposed to a 'hero's journey' narrative, such storytelling strategies arrange and organize experience in reciprocity with broader social context, thus serving to mediate the perceptions of others. The following brief excerpt from her oral history provides an example of how Doña Martina uses storytelling to make sense of planning practice under the discourse of socio-environmentalism.

In 1968, Doña Martina moved from Loma de Cabrera in the province of Dajabón near the Haitian border to
La Ciénaga, which at the time was a scarcely populated community with merely a handful of ranchitos (informal homes) surrounded by sugar cane. One of the earlier settlers gifted her a lot in an area that was so swampy, she recalls, that her husband did not want to build on the site. Prior to arriving in La Ciénaga, her husband served in the military while she had been working in the Helado Frijol factory. They used their savings and borrowed a bit more, allowing them to build a little wooden house in 1971 that remains her home today.

Doña Martina's work in the community began in 1983 with her junta de vecinos, and she has performed a variety of organizing roles since then. Early on, she helped form an organization that improved houses in the neighborhood and built the first school in La Ciénaga. Then-President Balaguer had prohibited the entering of materials and new construction into this area from 1986-1996, claiming that it might spread cholera. As Doña Martina recalls, "we had to sneak it in" since construction had to continue to meet the needs of the population.

In 1998, Doña Martina founded an organization called Sociedad de Madres y Niños Corazones de Jesús (Society of Mothers and Children Hearts of Jesus). She still runs the organization but laments that it is not the same as it once was. During previous governments, she was able to obtain milk and medicine more easily and cater to the needs of single women, pregnant women, and people with diabetes in the neighborhood. She would go to the public health office with a letter specifying the medicine residents needed, and the office would ensure they received it. But today, she says, "this government took away the milk, took away everything."

By recounting the episodic events that make sense of her life in the context of state involvement in the community, Doña Martina is able to note the contrasts between Plan Cigua, which she was instrumental in developing, and the current Domingo Savio plan. As she reflects on Plan Cigua, she recalls that home construction was allowed in the area where her home is located. However, in the Domingo Savio plan, all the houses in her block are marked for demolition. Lamenting the contradiction between this earlier bottom-up planning effort and the current strategies driven by the rationality of limpieza, Doña Martina says:

We worked really well with Navarro [then-head of Ciudad Alternativa, who led Plan Cigua]....We have a plan, but it was never executed because they [URBE] never saw it. URBE is doing whatever they want. Initially, we were with them [in support of them] because they sold us illusions. Then we turned the other way.... can't sit with people who ultimately want the destruction of the neighborhood.... If I go [get evicted] I will get sick and die. Because I know all the work that has happened here. All the work I have done here, all the work to get these four walls. 
As Sandercock (2003) posits, storytelling serves multiple functions in planning processes. In the case of Doña Martina's storytelling, she positions her personal life and community activism within the context of a series of government interventions that she has witnessed over many years, enabling her to retain a sense of active commitment to the community. The cultural reciprocity derived from material exchanges become organizing markers of episodic units over time, allowing Doña Martina to historicize efforts at redevelopment and thus make sense of the current discourse of socio-environmentalism and its economic and environmental imperatives: "They are planning to do something tourist-related" in this area, she says, in reference to the plan for a cruise terminal and greenways promoted in Nuevo Domingo Savio, and as a result her house is likely to be demolished.

\subsection{Speculation}

In addition to overt strategies of appropriation and storytelling, residents also deploy unsanctioned speech acts in their conversations to speculate about the impacts of planning strategies and thus imagine future community action. In doing so, Doña Martina, Evelin, and Alfonzo draw on a long oral tradition of sensemaking. As Derby (2019) suggests, "unsanctioned speech forms - the flourishes, the anecdotes, and the inadvertent details can reveal so much, and in the Dominican Republic, popular forms of speech such as banter, jokes, stories are high art."

The importance of rumor emerges clearly in community members' anecdotal dialogue about the threat of evictions resulting from Nuevo Domingo Savio. For example, Doña Martina reflects on past evictions in Los Guandules and says:

Here [in La Ciénega] they haven't started the evictions because we are still in the midst of all this, but see what they did in Los Guandules. In Los Guandules, there were people they gave 14,000 pesos to...even here they are valuing people's [houses] at 22,000 pesos...for a house made of zinc. I have witnessed a lot of evictions right here, but I have never seen anything like this....It might be a house of zinc but it is also their mansion...it's their mansion because it was what they could buy. They come and they knock it down.

As Derby (2014) notes, speculative rumor in this case enables Doña Martina to "transgress the opposition between the imaginative and the material (p. 132)," thus revealing a rich, layered historical relationship with the state that is described through embodied relations with materiality, in this case residents' houses.

Similarly, Evelin illustrates how informal banter enables personal experiences and ideas to transcend the private sphere and become shared public knowledge. Evelin's manner of switching between 'we' and 'they' pronouns also demonstrates her ability to empathize with those threatened with evictions because of the constant precarity the community faces. Speculating about the evictions following Nuevo Domingo Savio in a conversation with Vasudevan, a longtime organizer, and her own husband, Evelin says that the best option would be for the government to build apartments within the neighborhood so people could stay in place. But then she pauses, turns to her husband and says, "but if they [government] start it, will they finish it?" She describes how in the past, residents in other river communities were given temporary shelter as apartments were being built, but projects were never finished and they ended up having to stay permanently in the shelters. She goes on:

And that's the insecurity that we have, will we be given the apartments or not, and it's another thing if we are given the apartments-what's the security we have that the state [party in power] won't change and snatch away the apartments? [Turning to Vasudevan] We aren't against the project because the project will rid me of this headache [contamination of the river]. I am in favor of the project, I'm just not in favor of how they [the residents being evicted] are being treated.

Evelin then switches to gossip, another unsanctioned speech act designed to manage complex situations (Derby, 2014), suggesting that some homeowners may have a second home in Los Guandules and will resettle there: "I am not defending the ones that have another home. I am defending those who don't have what is needed to live, who have spent all their lives living here, and for whom 300,000 pesos will not do anything." Finally, she turns to the organizer accompanying Vasudevan and says:

You tell me, what can I do with 300,000 pesos? Or to be a house owner and get 18,000 pesos? Thank God I do not have a house over there [He nods his head in agreement] No, not even where I live. The cheapest house [there] is about 900,000 pesos.

Residents in other, nearby river communities also deploy gossip, rumor, and banter to make sense of government interventions and evictions. Alfonzo, a long-time resident and community organizer in La Zurza, turns to Nuevo Domingo Savio and the Nueva Barquita development when reflecting on the current lack of government support in La Zurza. While ruminating on the effects of a full-scale (Nueva Barquita) vs. partial (Nuevo Domingo Savio) relocation of residents, Alfonzo says: "Here in this country, when businesses take over a project, it gets done." Speculating on the prospect of compensation to residents who have been evicted as a result of the Nuevo Domingo Savio development, he turns his banter towards the situation in La Zurza:

It's not only over there [in Los Guandules and La Ciénaga].... Here in La Zurza people were evicted be- 
cause of the construction of the metro [in 2008] and the government has not answered to these families. These families now live on the banks of the river.

In this way, organizers utilize what they hear about government interventions and consequences in other communities to make sense and relate it back to their own communities.

Ultimately, as Derby (2014) notes, vernacular speech genres such as rumor, gossip and banter reveal how residents manage, resist, or reframe what is happening in their lives, allowing them to make sense of paradoxical and contradictory state interventions and project possible future scenarios. From the earliest days of their founding, Los Guandules, La Ciénaga, and La Zurza have experienced a series of planning projects resulting in resident displacement, only to see the retreat of state agencies and the return of residents to the neighborhood in a confounding cycle of re-informalization. The constant prospect of redevelopment coupled with the threat of displacement have added a deep sense of uncertainty to the social, economic and environmental precarity lived by residents. To manage this sense of uncertainty, residents turn to speculative speech forms to make sense of the vicissitudes of planning regimes that strive to evict residents from river communities only to see them return to their homes once the machinery of the state disappears. As Evelin says: "Each (government) has its own leadership and its own vision," that is to say, it makes sense that state planning interventions are cyclical expressions of shifting political priorities under evolving discourses of development.

\section{Conclusion}

In Santo Domingo, local and global concerns around climate change are deployed as justification for the massive redevelopment projects that are now reconfiguring river communities in the Ozama-Isabela river basin. The discourse of socio-environmentalism coupled with the rationality of limpieza and the visible spectacles of major infrastructure projects allow state and planning agents to prioritize near-term care for the environment over the needs and priorities of residents, even though they have long been stewards of the environment. Residents are asked to continue to be responsible for their own welfare, even though disruptive state interventions in the name of limpieza threaten residents' very ability to stay on the land and in the homes that they have built. The unpredictable redevelopment efforts in La Ciénaga and Los Guandules over time, combined with a fractured planning landscape in Santo Domingo, has left residents in a state of suspension as they observe the significant material and social changes taking place in their communities.

Yet, we would suggest that these tactics are not limited to the Dominican Republic. Rather than engaging in a dialectical process to simultaneously address both social and environmental concerns, cities in the 'global south' continue to be characterized by planning regimes that engage in modernist planning projects that foreground development that benefits the few, leaving the majority to face precarity and the threat of eviction. Additionally, neoliberalism has had the effect of fracturing planning landscapes in cities across the 'global south' while placing the responsibility on residents for their own well-being. Moreover, given the current global preoccupation with climate change, socio-environmental discourses serve to obscure the social implications of redevelopment interventions pursued in the name of climate mitigation, resilience, and sustainability.

However, we suggest that the concept of sensemaking constitutes an important resource for bottom-up community planning, particularly in neoliberal contexts characterized by fractured planning regimes bolstered by a discourse of socio-environmentalism. First, by appropriating and deploying technocratic planning language, residents advocate for themselves in official spaces despite the opacity and unpredictability of planning projects. Second, storytelling enables them to maintain strong social relations and foster a historical understanding of planning interventions. Oral histories serve to communicate the values residents place on their land and waters, illustrating how residents maintain a strong social fabric while caring for their communities. Material objects and exchanges become important episodic markers of community-government relationships, informing retrospective understanding of community expectations, disappointments, and resistance. Third, rumors, gossip, banter, and other unsanctioned speech acts are an important resource for residents, especially as they contend with fragmented planning regimes and devise new possibilities for community-based action. We suggest that these variable sensemaking strategies are particularly significant in 'global south' planning contexts characterized by unequal relations of power, lack of transparency, and conflicting rationalities (Watson, 2009), constituting an important source of agency for residents to critically assess the illusions and realities of complex and opaque planning processes.

\section{Acknowledgments}

This work was supported by the National Science Foundation International Research Experience for Students Program [IRES Award No. IIA-1358127]; the Environmental Protection Agency P3 Program; the Fulbright U.S. Student Program to the Dominican Republic; and the School of Architecture, the Lozano Long Institute of Latin American Studies, and the Global Research Fellowship at the University of Texas at Austin. We are grateful to the residents of Los Platanitos, Los Guandules, La Ciénaga, and La Zurza and to the many government institutions, private companies and nongovernmental organizations in the Dominican Republic who assisted with our field research. In particular, 
we offer thanks to Juan Torres with the Ministerio de Obras Públicas and La Dirección de Planeamiento Urbano, Distrito Nacional. We also wish to thank Anja Nygren, Florencia Quesada, and the three anonymous reviewers who provided highly valuable comments on our manuscript.

\section{Conflict of Interests}

The authors declare no conflict of interests.

\section{References}

Alcaldía Distrito Nacional. (n.d.). Campaña de educación ciudadana [Citizen education campaign]. Alcaldía del Distrito Nacional. Retrieved from http://adn.gob.do/index.php?option=com_content \&view $=$ article \&id $=858 \&$ Itemid $=843$

Alcaldía Distrito Nacional. (2019). Ordenamiento territorial para el desarrollo de Santo Domingo [Territorial planning for the development of Santo Domingo]. Santo Domingo: Alcaldía Distrito Nacional.

Balbo, M. (1993). Urban planning and the fragmented city of developing countries. Third World Planning Review, 15(1), 23-35.

Bosman, M., \& Amen, M. (2006). Recasting neoliberalism in the Americas: A critique of the preliminary needs assessment of the Millennium Development Goals in the Dominican Republic. Globalizations, 3(2), 227-236.

Chantada, A. (2014). The state, the city, and participation in civil society in the Dominican Republic. Planning Theory \& Practice, 15(4), 565-588.

Codecigua with Ciudad Alternativa. (2004). Plan Cigua: Plan de desarollo urbano para La Ciénaga y Los Guandules [Plan Cigua: Urban development plan for La Ciénaga and Los Guandules]. Santo Domingo: Ciudad Alternativa.

Comisión Presidencial. (2015). Plan estratégico OzamaIsabela [Ozama-Isabela strategic plan]. Santo Domingo: Comisión Presidencial.

Dagnino, E. (2006). Meanings of citizenship in Latin America. Canadian Journal of Latin American and Caribbean Studies, 31(62), 15-51.

Derby, L. (2014). Beyond fugitive speech: Rumor and affect in Caribbean history. Small Axe: A Caribbean Journal of Criticism, 18(2), 123-140.

Derby, L. (2019, December 30). Documenting the Cold War in the Dominican Republic [Video file]. Retrieved from https://www.youtube.com/watch?v= U3nOi74_6sU\&feature=youtu.be

Goldfrank, B., \& Schrank, A. (2009). Municipal neoliberalism and municipal socialism: Urban political economy in Latin America. International Journal of Urban and Regional Research, 33(2), 443-462.

Gunder, M., \& Hillier, J. (2007). Planning as urban therapeutic. Environment and Planning A, 39(4), 467-486.

Gutiérrez, W. (2014). Recopilación documental de informaciones relacionadas con la cuenca, calidad de sus aguas, el saneamiento y rehabilitación del Rio Ozama [Documentary collection of information related to the basin, its water quality, and the sanitation and rehabilitation of the River Ozama]. Santo Domingo: Coalición Río. Retrieved from http:// www.coalicionrio.org/site/images/documentos/ proyectos/ozama/recopilacion-documentales-sobrela-cuenca-ozama.pdf

Hutter, G., \& Kuhlicke, C. (2013). Resilience, talk and action: Exploring the meanings of resilience in the context of planning and institutions. Planning Practice \& Research, 28(3), 294-306.

International City/County Management Association. (2018). Planning for climate adaptation program: Final report (Cooperative Agreement Award No. AID 517-A-15-00003). Santo Domingo: United States Agency for International Development.

Koch, F. (2015). The rules of the game and how to change them: Urban planning between formal and informal practices: A Colombian case study. International Planning Studies, 20(4), 407-423.

Kudva, N. (2009). The everyday and the episodic: The spatial and political impacts of urban informality. Environment and Planning A, 41, 1614-1628.

Larbi, W. O. (1996). Spatial planning and urban fragmentation in Accra. Third World Planning Review, 18(2), 193-214.

Little, R. M., \& Froggett, L. (2009). Making meaning in muddy waters: Representing complexity through community based storytelling. Community Development Journal, 45(4), 458-473.

Ministerio De Economía, Planificación Y Desarrollo. (n.d.). Estrategia nacional de desarrollo 2010-2030: Un viaje de transformación hacia un país mejor [National development strategy 2010-2030: A journey of transformation towards a better country]. Santo Domingo: Ministerio De Economía, Planificación Y Desarrollo.

Miraftab, F. (2009). Insurgent planning: Situating radical planning in the global south. Planning Theory, 8(1), 32-50.

Polkinghorne, D. (1988). Narrative knowing and the human sciences. Albany, NY: State University of New York Press.

Raco, M. (2007). Securing sustainable communities: Citizenship, safety and sustainability in the new urban planning. European Urban and Regional Studies, 14(4), 305-320.

Roy, A. (2005). Urban informality: Toward an epistemology of planning. Journal of the American Planning Association, 71(2), 147-158.

Roy, A. (2009). Why India cannot plan its cities: Informality, insurgence and the idiom of urbanization. Planning Theory, 8(1), 76-87.

Rydin, Y. (2007). Indicators as a governmental technology? The lessons of community-based sustainability indicator projects. Environment and Planning D: Society and Space, 25, 610-624. 
Sandercock, L. (2003). Out of the closet: The importance of stories and storytelling in planning practice. Planning Theory and Practice, 4(1), 11-28.

Shamir, R. (2008). The age of responsibilization: On market-embedded morality. Economy and Society, 37(1), 1-19.

Sletto, B. (2013). Insurgent planning and its interlocutors: Studio pedagogy as unsanctioned practice in Santo Domingo, Dominican Republic. Journal of Planning Education and Research, 33(2), 228-240.

Sletto, B., \& Nygren, A. (2016). Unsettling neoliberal rationalities: Engaged ethnography and the meanings of responsibility in the Dominican Republic and Mexico. International Journal of Urban and Regional Research, 39(5), 965-983.

Sletto, B., Tabory, S., \& Strickler, K. (2019). Sustainable urban water management and integrated development in informal settlements: The contested politics of coproduction in Santo Domingo, Dominican Republic. Global Environmental Change, 54, 195-202.
Swilling, M. (2014). Contesting inclusive urbanism in a divided city: The limits to the neoliberalisation of Cape Town's energy system. Urban Studies, 51(15), 3180-3197.

Swyngedouw, E. (2005). Governance innovation and the citizen: The Janus face of governance-beyond-thestate. Urban Studies, 42(11), 1991-2006.

Thomas, J. M. (2004). Neighborhood planning: Uses of oral history. Journal of Planning History, 3(1), 50-70.

Watson, V. (2009). Seeing from the south: Refocusing urban planning on the globe's central urban issues. Urban Studies, 46(11), 2259-2275.

Weick, K. E., Sutcliffe, K. M., \& Obstfeld, D. (2005). Organizing and the process of sensemaking. Organization Science, 16(4), 409-421.

Woolford, A., \& Nelund, A. (2013). The responsibilities of the poor: Performing neoliberal citizenship within the bureaucratic field. Social Service Review, 87(2), 292-318.

\section{About the Authors}

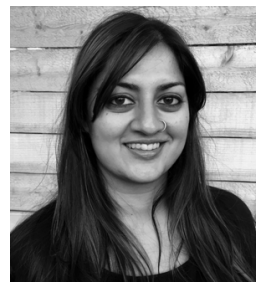

Raksha Vasudevan received her PhD in Community and Regional Planning from the University of Texas in Austin. Her work lies at the intersection of youth geographies, spatial justice, and arts-based research to interrogate how young people stake claim to city spaces. Apart from her ongoing feminist ethnographic project in the Dominican Republic, Raksha worked as an Intern Architect and Elementary School Teacher, and managed the sustainability program for a membership organization of local elected officials.

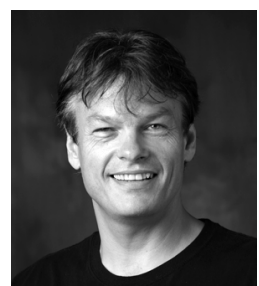

Bjørn Sletto works with partner institutions in Latin America to further interdisciplinary scholarship on representational politics and social justice in vulnerable communities, while teaching environmental and social justice and international planning and development. His research specifically examines indigenous land rights, informal infrastructures, and environmental planning in Latin America, particularly in Venezuela, Colombia and the Dominican Republic. His latest book is Radical Cartographies: Participatory Mapmaking from Latin America (UT Press). 